\title{
Pola Pemberdayaan Ekonomi Masyarakat Melalui Pengembangan Dan Perluasan Usaha Cibay Di Kabupaten Cirebon
}

\author{
Syaeful Bakhri ${ }^{1 *}$, Oki Khairul Hikmah ${ }^{2}$, Shofi Nurrohmah ${ }^{3}$ \\ IAIN Syekh Nurjati Cirebon \\ 1e-mail: sultan01aulia@yahoo.com \\ 2e-mail: okikhairulhikmah2000@gmail.com \\ 3e-mail: shofinurrohmah757@gmail.com \\ *Corresponding Author
}

\begin{abstract}
ABSTRAK
Merujuk peranan sebuah Perguruan Tinggi yaitu bidang Pendidikan, penelitian dan Pengabdian kepada masyarakat, pemberdayaan tidak harus berkonotasi kerja monumental, namun kerja pendampingan dan pemberdayaan pada sektor usaha kecil dan menengah yang juga bisa dilakukan oleh kampus. Pola pemberdayaan ekonomi melalui usaha cibay sangat membantu sektor kerja informal, membuka lapangan kerja sekaligus usaha. Pola kerjasama dengan franchise bagi masyarakat yang memiliki modal usaha, atau cukup dengan bergabung menjadi reseller untuk yang minim modal. Pelaksanaan pendampingan dengan terlibat proses produksi, packing hingga prosess marketing didapatkan beberapa perbaikan dan usulan inovasi seperti packing menggunakan vacuum sealer sehingga menjadikan cibay lebih tahan lama hingga ke tangan konsumen. Perlu strategi pengembangan yang terus menerus dan marketing yang inovatif agar produk olahan ini dapat menjadi salah satu ikon makanan khas cirebon.
\end{abstract}

Kata Kunci: Pemberdayaan Ekonomi; Pendampingan; Kemitraan

\begin{abstract}
Referring to the role of a tertiary institution, namely the fields of education, research, and community service, empowerment does not have the connotation of monumental work, but mentoring and empowerment work in the small and medium business sector which can also be carried out by the campus. The pattern of economic empowerment through the Cibay business is very helpful for the informal work sector, opening jobs as well as businesses. The pattern of cooperation with franchises for people who have business capital, or enough to join as a reseller for those with minimal capital. Implementation of assistance by involved in the production process, packing to the marketing process, obtained several improvements and proposed innovations such as packing using a vacuum sealer so that Cibay is more durable in the hands of consumers. It needs a continuous development strategy and innovative marketing so that this processed product can become one of Cirebon's signature food icons.
\end{abstract}

Keywords: Economic Empowerment; Assistanc; Partnership 


\section{PENDAHULUAN}

Pemberdayaan memiliki arti yang sangat luas, membangun kemandirian baik secara sosial, ekonomi, budaya dan bahkan politik. Menurut Kartasasmita dalam (Tampubolon, Ginting Sugihen, Samet, Susanto, \& Sumardjo, 2006), pemberdayaan biasanya memiliki dua arah, yaitu berupaya untuk melepaskan belenggu kemiskinan dan keterbelakangan, serta berupaya memperkuat posisi lapisan masyarakat dalam struktur kekuasaan. Kemampuan melakukan pemberdayaan mempunyai arti yang sama dengan kemandirian masyarakat. Terkait dengan program pembangunan, bahwa tujuan yang ingin dicapai adalah untuk membentuk individu dan masyarakat menuju masyarakat yang mandiri (Widjajanti, 2011) dan terlepas dari belenggu kemiskinan.

Salah satu kemandirian ekonomi yang dibangun oleh sebagian masyarakat kita adalah membangun usaha mandiri (wirausaha) baik melalui ide usaha mandiri maupun melalui metode yang sering disebut oleh banyak di industri kreatif dengan ATM (Amati, Tiru dan Modifikasi). Hal ini sesuai dengan pendapat (Putra, 2016) yang menyebutkan bahwa semakin maju suatu negara, maka semakin banyak orang yang terdidik, banyak pula orang yang menganggur dan disinilah arti penting dunia wirausaha atau usaha mandiri. Banyak pola pola yang dibangun ditengah masyarakat, dengan menggunakan sistem usaha kerjasama, hubungan investor dan pelaku usaha, waralaba (franchise) dan banyak bentuk model kerjasama usaha lainya.

Usaha Mikro, Kecil dan Menengah merupakan pemain penting dalam pengembangan kegiatan ekonomi lokal dan pemberdayaan masyarakat. UMKM berperan untuk pertumbuhan ekonomi dan penyerapan tenaga kerja. selain itu, UMK juga berperan sebagai sarana distribusi dari pada hasil-hasil pembangunan (Putra, 2016). Odari pengertian tersebut, dapat didefinisikan bahwa UMKM adalah salah satu bentuk usaha mandiri yang mampu menjadi bagian indikator ekonomi yang layak diperhitungkan dalam peningkatan perekonomian nasional. (Nurdiyanto \& Meilia, 2016) Kondisi tersebut dapat dilihat dari berbagai sumber data yang mendukung tentang eksistensi UMKM yang cukup dominan dalam perekonomian Indonesia khususnya Kabupaten Cirebon. Potret tersebut dapat diketahui dari pergerakan industri pengolahan yang cenderung terus mengalami pertumbuhan. Seperti yang dijelaskan pada tabel 1. yang memberikan gambaran pergeseran enam sektor PDRB dengan kontribusi tertinggi terhadap PDRB Kabupaten Cirebon pada tahun 2015 hingga tahun 2018. 
Tabel 1.

Enam Sektor PDRB Dengan Kontribusi Tertinggi Terhadap PDRB Kabupaten Cirebon Tahun 2015-2018 (dalam persen)

\begin{tabular}{lrrrr}
\hline \multirow{2}{*}{ Lapangan Usaha } & \multicolumn{4}{c}{ Tahun } \\
\cline { 2 - 5 } & $\mathbf{2 0 1 5}$ & $\mathbf{2 0 1 6}$ & $\mathbf{2 0 1 7}$ & $\mathbf{2 0 1 8}$ \\
\hline Industri Pengolahan & 20,62 & 20,65 & 20,66 & 20,68 \\
Perdagangan Besar dan Eceran; & 16,26 & 15,95 & 15,85 & 15,58 \\
Reparasi Mobil dan Sepeda Motor & & & & \\
Pertanian, Kehutanan, dan Perikanan & 14,90 & 14,96 & 14,46 & 14,07 \\
Konstruksi & 12,18 & 12,10 & 12,01 & 12,24 \\
Transportasi dan Pergudangan & 7,33 & 7,45 & 7,54 & 7,61 \\
Jasa Pendidikan & 5,08 & 5,11 & 5,32 & 5,47 \\
\hline Jumlah & $\mathbf{7 6 , 3 6}$ & $\mathbf{7 6 , 2 2}$ & $\mathbf{7 5 , 8 4}$ & $\mathbf{7 5 , 6 5}$ \\
\hline
\end{tabular}

Sumber: BPS 2019, diolah.

Ke enam sektor lapangan usaha tersebut mendominasi terhadap kontribusi PDRB Kabupaten Cirebon selama empat tahun terakhir dengan perkembangan kontribusi yang relatif stabil dan didominasi oleh sektor Industri Pengolahan yang secara total menyumbangkan lebih dari $20 \%$ perekonomian Kabupaten Cirebon. Kabupaten Cirebon merupakan daerah potensial yang letaknya sangat strategis untuk pengembangan industri ekonomi karena didukung oleh posisi strategis, aksesibilitas yang mudah serta sarana dan prasarana pendukung yang cukup memadai membuat Kabupaten Cirebon menjadi pilihan alternatif bagi para investor industri sedang dan besar untuk mengembangkan usahanya. Dengan potensi alam dan dukungan dari berbagai aspek tersebut akan berpeluang menumbuhkan iklim usaha industri yang baik (termasuk UMKM). Hal ini menunjukkan bahwa Kabupaten Cirebon perlu untuk dapat fokus mengoptimalkan industri pengolahan (termasuk UMKM) agar tetap mampu memberikan kontribusi ekonomi yang optimal terhadap perekonomian daerah ditengah potensi dan peluang yang dimiliki Kabupaten Cirebon secara umum.

Cibay merupakan singkatan dari cireng lebay, produk makanan olahan yang terbuat dari tepung tapioka yang dibungkus dengan balutan kulit lumpia. Rasanya yang renyah di luar dan aci yang lebay di dalam menjadi sebuah keunikan tersendiri dibandingkan dengan jajanan/ cemilan makanan lainnya. Indusri Kecil Menengah (IKM) ini merupakan salah satu UMKM yang mulai didirikan pada bulan Desember tahun 2016 dan saat ini tengah berkembang di Kota dan Kabupaten Cirebon. Seiring dengan perkembangan dan perluasan usahanya tersebut, tentu sedikit banyaknya 
telah berkontribusi terhadap pemberdayaan ekonomi masyarakat sekitar. Karena ketika kita mempelajari pertumbuhan suatu usaha maka itu berarti kita juga mempelajari kontribusinya terhadap perekonomian masyarakat pada suatu wilayah termasuk dalam memberdayakan ekonominya. Terjadinya penambahan jumlah unit suatu usaha (termasuk IKM cibay) maka dapat meningkatkan kebutuhan tenaga kerja, meluasnya keterlibatan interaksi dan kapasistas masyarakat serta peningkatan pemerataan pendapatan yang ditandai dengan peningkatan pendapatan keluarga (khususnya keluarga miskin). Peningkatan tersebut kemudian berdampak pada penetuan kualitas pemenuhan kebutuhan ekonomi masyarakat dan kesejahteraan masyarakat. Kegiatan pendampingan ini penting dilakukan untuk mengetahui pola-pola pemberdayaan ekonomi masyarakat seiring dengan pengembangan dan perluasan usaha cibay di kabupaten cirebon. Dari pendampingan tersebut diharapkan mendapatkan informasi yang komprehensif, sehingga setelah menemukan masalah juga dapat ditemukan solusi seputar pengembangan dan pemberdayaan ekonomi masyarakat melalui pengembangan usaha cibay.

\section{BAHAN DN METODE}

Metode Pelaksanaan Pengabdian diawali dengan melakukan identifikasi usaha cibay melalui beberapa kali survey lapangan yang dilakukan oleh tim pengabdi dengan menentukan lokasi, dan pihak mana saja yang dapat memberikan informasi pada kegiatan ini. Setelah melalui proses survey lokasi dan diskusi tim, di putuskan untuk menentukan beberapa narasumber, yaitu ; (1) Owner/ founding/ Pemilik usaha cibay (2) Mitra Franchise (3) Mitra Reseller dan (4) Konsumen Cibay.

Setelah menentukan narasumber, kita menentukan teknik pengumpulan data dan informasi dalam kegiatan pendampingan ini agar berjalan dengan baik dilakukan melalui cara;

1. Observasi, yaitu tim pendamping mengumpulkan data dan informasi dari sumber data primer yang melibatkan pemantauan aktivitas dan kondisi perilaku seseorang.

2. Brainstorming/ diskusi / wawancara, dengan narasumber yang sudah kita tentukan yaitu kegiatan ini dilakukan bersamaan dengan observasi. Kegiatan ini bertujuan untuk memperoleh data secara mendalam karena dilakukan secara langsung dengan mengajukan beberapa pertanyaan kepada informan/ narasumber.

3. Studi dokumentasi, yaitu tim pendamping mengumpulkan data dan informasi berupa catatan tertulis yang tersimpan terkait dengan masalah yang diteliti oleh tim pendamping. Studi dokumentasi ini dapat membantu memahami fenomena, interpretasi, menyusun teori sekaligus mampu memvalidasi data.(Indrawan \& Yaniawati, 2017). 
Adapun beberapa landasan teori yang penulis gunakan sebagai bahan dalam pelaksanaan dan penyusunan karya ilmiah pengabdian ini, antara lain sebagaimana berikut ini:

Pemberdayaan adalah serangkaian upaya mengubah atau mengembangkan seseorang/ kelompok yang semula dalam keadaan tidak atau kurang berdaya menjadi berdaya (memiliki daya) agar dapat mencapai kehidupan yang lebih baik. (Rifa'i, 2013) menjelaskan bahwa kepemilikan daya tersebut selanjutnya membantu masyarakat untuk mengambil keputusan sebagai bentuk penentuan tindakan yang akan mereka lakukan yang terkait dengan diri mereka sendiri, termasuk mengurangi efek hambatan pribadi dan sosial dalam melakukan tindakan Menurut Sumodiningrat, secara konkrit dalam upaya pemberdayaan masyarakat dilakukan melalui pembangunan ekonomi rakyat, sementara itu, pengentasan kemiskinan adalah langkah utama yang harus dilakukan dalam pembangunan ekonomi rakyat. Sumodiningrat juga menambahkan, dalam pemberdayaan masyarakat tersebut, tidak harus mencakup lima hal pokok berupa penyediaan sarana, pembangunan prasarana, pemberian bantuan modal usaha, pelatihan bagi aparat dan masyarakat dan penguatan kelembagaan sosial ekonomi masyarakat. Menurut (Tampubolon et al., 2006), dalam upaya pemberdayaan masyarakat, dapat dilihat pada tiga sisi, diantaranya:

1. Pertama, enabling, adalah kemampuan menciptakan kondisi iklim yang memungkinkan potensi masyarakat berkembang. Disini kuncinya adalah mengenalkan dan mengingatkan bahwa tidak ada manusia, individu masyarakat yang tidak memiliki potensi atau daya yang dapat dikembangkan. Oleh karenanya pemberdayaan disini berperan untuk membangun dan mengembangkan potensi atau daya tersebut, dengan cara membangkitkan kesadaran masyarakat atas potensi yang dimiliki, memotivasi mereka, serta mendorong mereka agar dapat mengembangkan potensi atau daya yang ada dalam diri masyarakat.

2. Kedua, empowering, memperkuat potensi atau daya yang dimiliki masyarakat. Dalam rangka ini diperlukan langkah- langkah positif lainnya, selain dari pada hanya menciptakan iklim. Pembuakaan akses terhadap berbagai peluang akan sangat membantu masyarakat menjadi berdaya. Upaya utama dalam rangka pemberdayaan adalah dengan meningkatkan taraf pendidikan, kualitas kesehatan, juga akses menuju sumber-sumber kemajuan ekonomi berupaya permodalan, informasi dan teknologi, pasar dan lapangan pasar.

Dalam rangka pemberdayaan ini, perkuatan juga dilakukan melalui langkah- langkah konkrit yang selalu menyangkut penyediaan berbagai masukan (input). Masukan berupa pemberdayaan ini menyangkut pembangunan prasarana dan sarana dasar fisik, seperti irigasi, 
jalan, listrik, maupun sosial seperti sekolah dan fasilitas pelayanan kesehatan, yang dapat dijangkau oleh masyarakat pada lapisan paling bawah, serta ketersediaan lembaga-lembaga pendanaan, pelatihan, dan pemasaran di perdesaan, dimana terkonsentrasi penduduk yang keberdayaannya amat kurang. Untuk itu, perlu ada program khusus bagi masyarakat yang kurang berdaya, karena program-program umum yang berlaku tidak selalu dapat menyentuh lapisan masyarakat ini.

3. Ketiga, protecting, pemberdayaan dapat pula mengandung arti perlindungan. Dalam proses pemberdayaan, perlindungan dan pemihakan kepada masyarakat berdaya lemah sangat penting karena dapat mencegah masyarakat lemah menjadi semakin lemah karena kurang berdayanya mereka menghadapi yang kuat. Melakukan perlindungan tidak selalu mengisolasi atau menutupi dari interaksi, karena hal itu justru akan mengerdilkan yang kecil dan melunglaikan yang lemah. Melindungi disini bertujuan untuk mencegah terjadinya persaingan yang tidak seimbang dan potensi adanya eksploitasi yang kuat terhadap yang lemah. Pemberdayaan masyarakat bukan membuat masyarakat menjadi makin tergantung pada berbagai program pemberian (charity). Karena, pada dasarnya setiap apa yang dinikmati harus dihasilkan atas usaha sendiri (yang hasilnya dapat dipertikarkan dengan pihak lain).

\section{HASIL DAN PEMBAHASAN}

\section{Pola Pemberdayaan Ekonomi Masyarakat melalui pengembangan usaha Cibay}

Pemberdayaan merupakan suatu upaya untuk mengembangkan suatu potensi yang dimiliki oleh individu ataupun kelompok guna meningkatkan taraf hidupnya dengan memanfaatkan sumber daya yang ada guna mewujudkan hasil yang diinginkan dari suatu pemberdayaan yaitu berupa output dan outcome. Output adalah hasil langsung dari proses pemberdayaan yang dilakukan, sedangkan outcome adalah dampak perubahan yang diharapkan setelah adanya pemberdayaan. (Rifa'i, 2013). Dalam dunia bisnis, potensi atau daya yang dimaksud adalah kemampuan atau produktivitas. Pemberdayaan dapat diartikan sebagai proses peningkatan optimasi kemampuan produktivitas pada suatu usaha. Potensi atau daya disini dapat juga diartikan sebagai keunggulan dalam berdaya saing atau posisi tawar (Theresia, Andini, Nugraha, \& Mardikanto, 2014).

Pengembangan produk pada pelaku usaha dapat dilakukan melalui beberapa tahapan. Tahaptahap dalam pengembangan produk biasanya melibatkan seperti penetapan suatu ide, penyaringan ide, pengembangan ide, perlakukan percobaan, analisis usaha, percobaan penjualan dipasar dan ketika 
serangkaian tahapan tersebut berhasil maka pelaku usaha dapat memproduksinya secara massal. Tujuan pengembangan produk itu sendiri menurut (Alma, 2013) adalah untuk:

1. Memenuhi keinginan konsumen

2. Memenangkan persaingan

3. Meningkatkan jumlah penjualan

4. Mendayagunakan sumber-sumber produksi

5. Mencegah kebosanan konsumen

\section{Pola Kemitraan}

Dalam kerja sama pengembangan usaha dikenal istilah yang biasa disebut dengan pola kemitraan. Kemitraan usaha adalah jalinan usaha yang akan saling menguntungkan antar perusahaan mitra. Perusahaan yang bermitra akan saling memerlukan, menguntungkan dan memperkuat, sehingga jalinan kemitraan tersebut berpotensi menghasilkan efisiensi dan sinergi sumber daya para perusahaan dan akan menguntungkan semua pihak yang bermitra. Kemitraan juga mampu memperkuat mekanisme pasar dan persaingan usaha agar lebih produktif dan efisien. Kemitraan usaha hanya akan terjalin secara berkesinambungan dan efektif apabila kemitraan tersebut dapat dijalankan dengan kerangka berfikir yang mengarah pada pembangunan ekonomi, dan bukan sebatas konsep sosial yang berlandaskan motif belas kasihan maupun kedermawanan.(Santosa, Prihatini, Purwanto, Jumiati, \& Susilo, 2016).

Dalam pengembangan kerja sama usaha cibay ini pola kerjasama yang dijalankan melalui dua pola kerjasama kemitraan, yaitu ;

1. Franchise

Dalam (Karamoy, 2011) dijelaskan bahwa franchise (waralaba) merupakan suatu pola kemitraan usaha antara perusahaan yang memiliki Hak Kekayaan Intelektual (HKI) utamanya merk, dengan sistem manajemen, keuangan dan pemasaran yang telah mantap (established). Dalam pelaksanaannya, waralaba dapat diartikan sebagai peristiwa peminjaman atau penggunaan (bukan pengalihan) HK yang telah diatur oleh kontrak perjanjian, maka ketika merek dan sistem belum dipijamkan maka belum dapat dikatakan sebagai pola waralaba.

Franchise merupakan suatu bentuk sinergitas usaha yang ditawarkan oleh suatu pelaku usaha/perusahaan yang sudah memiliki kinerja unggul karena didukung oleh sumber daya 
berbasis pengetahuan dan orientasi kewirausahaan yang cukup tinggi dengan tata kelola yang baik. Tawaran ini dapat dimanfaatkan oleh pihak lain dengan melakukan hubungan kontraktual untuk menjalankan bisnisnya dengan imbalan yang telah disepakati dalam perjanjian.(Rachmadi, 2007)

Pola usaha waralaba memberikan kemudahan dalam mengembangkan usaha. Franchisor dapat mempercepat pertumbuhan outletnya dengan tidak perlu menunggu terkumpulnya modal karena Franchisee (pembeli hak franchise)/investor yang akan memberikan modal. Dengan pola tersebut maka jaringan dapat dengan cepat meluas. Selain itu usaha waralaba memiliki ketahanan yang baik dalam menghadapi berbagai risiko usaha. Sementara bagi Franchise, tidak perlu pengalaman bisnis yang memadahi dan akan memperoleh bantuan teknis terkait pelaksanaan usahanya. (Tim Penelitian dan Pengembangan Perkreditan dan UMKM, 2009)

2. Reseller

Merupakan orang yang melakukan penjualan atas produk orang lain dengan sebuah kesepakatan yang telah ditetapkan sebelumnya. Melalui reseller, owner atau supplier dapat memperluas pemasaran produknya sebagai strategi distribusi tidak langsung. Distribusi tidak langsung sendiri adalah penjualan barang dari produsen kepada konsumen melalui perantara. Reseller akan mendapatkan keuntungan karena mendapatkan harga yang lebih rendah dibanding harga pasaran. Maka dalam hal ini, pola kerjasama yang dilakukan akan tetap berdampak baik dan menghasilkan keuntungan bagi kedua belah pihak. Tujuan dari sistem reseller yaitu memudahkan para wirausaha untuk menjalankan aktivitas usahanya melalui media sosial yang digunakan dan untuk memanfaatkan peluang kebutuhan masyarakat yang saat ini lebih memilih cara instan dengan pemesanan suatu produk secara online melalui penggunaan kemajuan teknologi saat ini. (Hasanah, 2019). Berikut perbedaan kedua pola kerjasama yang dilakukan dalam pengembangan usaha cibay;

Tabel 2. Pola kerjasama pengembangan usaha cibay

\begin{tabular}{ll}
\hline \multicolumn{1}{c}{ Franchise } & \multicolumn{1}{c}{ Reseller } \\
\hline - Modal usaha relatif lebih besar & - \\
berkisar 9-17 juta & minimal 200 ribu sudah dapat \\
& bergabung dengan usaha cibay \\
\hline
\end{tabular}




\section{Franchise}

- Di fasilitasi dengan gerobak atau meja portable

- Disediakan payung kain untuk fasilitas meja portable

- Disediakan kompor dan alat penggorengan

- Diberikan bonus cibay siap goreng 500 pcs

\section{Reseller}

- Diperbolehkan bergabung dengan usaha dan dagangan yang lain

- Tidak difasilitasi gerobak /meja potable /payung dan lainya

- Terdapat ketentuan target penjualan harian

Sumber: Data primer, 2020

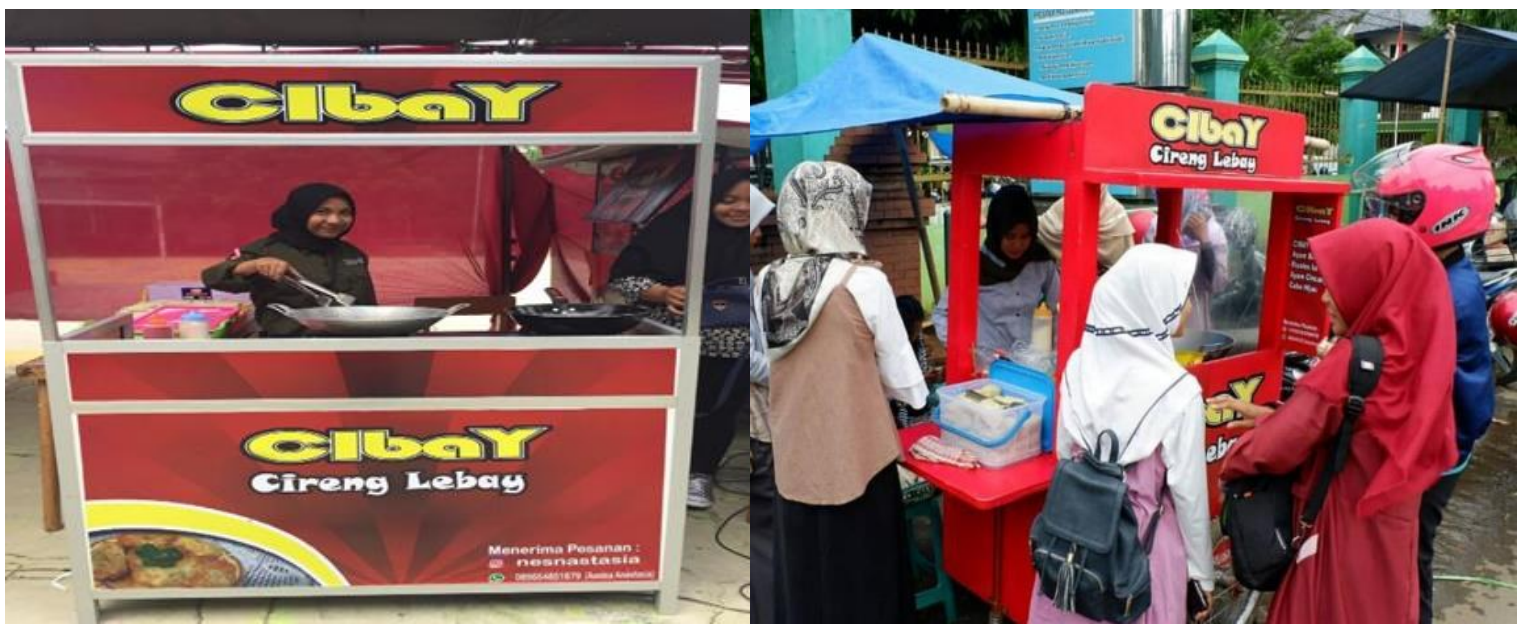

Gambar 1. fasilitas meja portable

Gambar 2. fasilitas gerobak

\section{Pola Pengembangan Produksi}

Pengembangan produksi merupakan salah satu upaya mencapai peningkatan penjualan melalui peningkatan kemampuan produksi. Adapun proses pembuatan cibay secara singkatnya dapat diketahui sebagaimana berikut:

1. Menyiapkan bahan-bahan untuk adonan cibay

2. Panaskan adonan diatas api sambil mengaduk hingga adonan mengental

3. Bentuk dan bungkus adonan secara manual dengan dilapisi kulit lumpia 


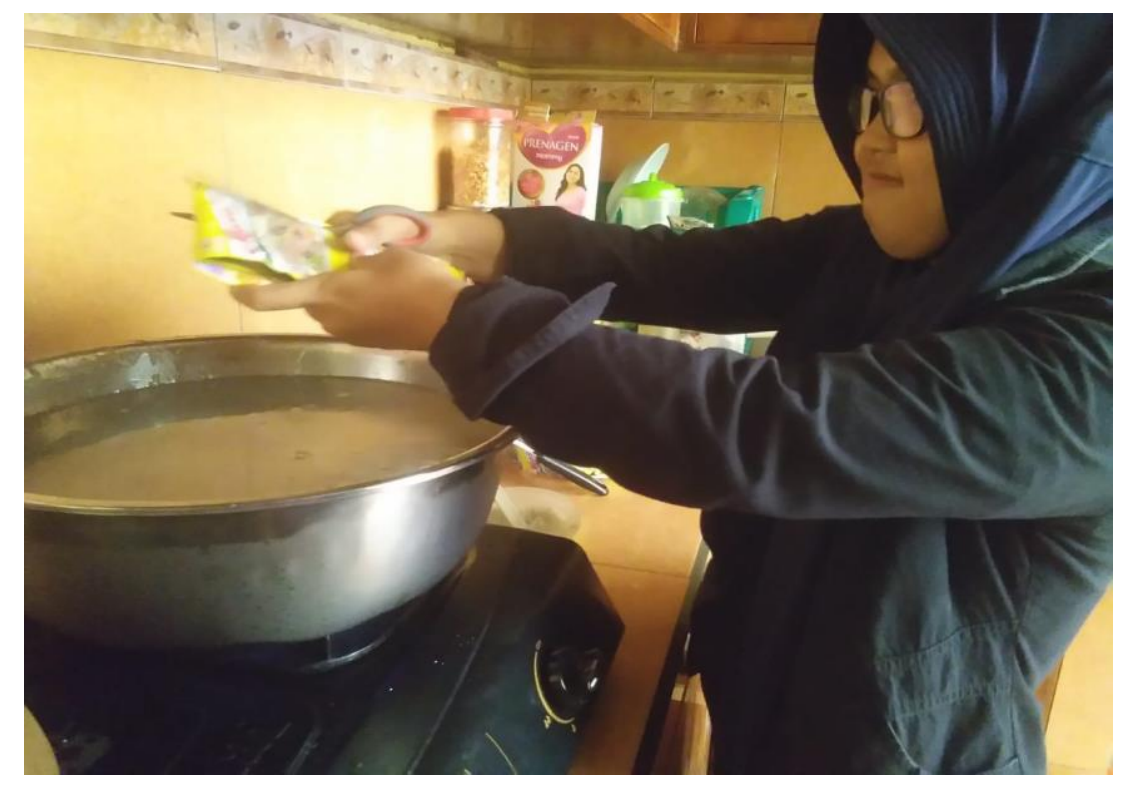

Gambar 3. Dokuemntasi Proses Pembuatan Adonan cibay

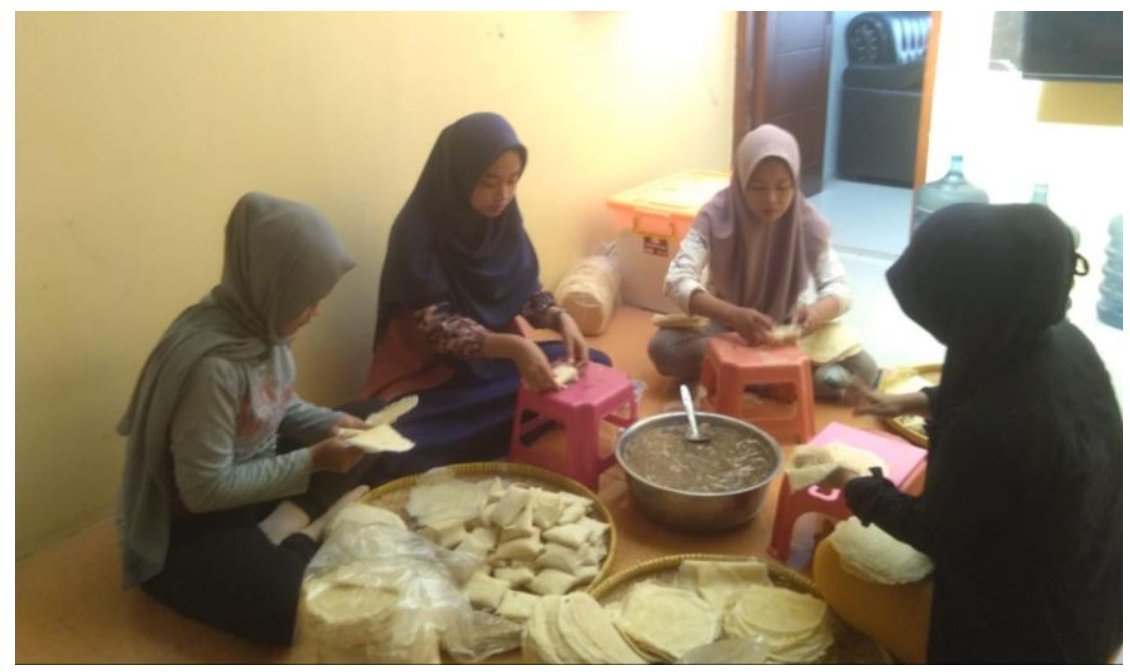

\section{Gambar 4. Dokumentasi Proses Pembentukan dan Pembungkusan Produk cibay}

Setelah proses pencetakan selesai, cibay diletakkan pada showcase cooler, yaitu sebuah alat pendingin menyerupai kulkas yang berfungsi untuk menyimpan dan memajang makanan dengan tujuan untuk mengawetkan cibay agar dapat memperpanjang masa simpan produk tersebut. Setelah itu cibay akan dipasarkan kepada franchise, reseller maupun konsumen secara langsung. Dalam pola pengembangan produksi, tim pendamping mengarahkan agar produksi cibay dapat dilakukan menggunakan mesin. Mesin merupakan salah satu faktor produksi berupa sumber daya modal, selain menjadi penyimpan kekayaan, mesin juga berfungsi sebagai alat yang dapat membantu meningkatkan output produktivitas dan menurunkan biaya dalam jangka yang panjang agar kegiatan produksi dapat 
berjalan secara efektif dan efisien. Adapun strategi ini kini masih dalam proses pengupayaan, agar dapat menghasilkan mesin produksi yang tepat dan bekerja secara optimal.

\section{Rekruitmen dan Pengembangan Tenaga Kerja}

Rekrutmen tenaga kerja pada hakikatnya adalah sebuah proses penentuan dan penarikan pelamar kerja agar dapat bekerja di dalam suatu perusahaan. Rekrutmen bertujuan untuk membantu dan meningkatkan keberhasilan proses pemilihan tenaga kerja yang sesuai syarat dan kebutuhan perusahaan.

Keuntungan dari kebutuhan tenaga kerja di sektor informal seperti usaha cibay ini adalah tidak terlalu membutuhkan tenaga profesional atau dengan pendidikan tertentu. Karena kebutuhan tenaga kerja yang dibutuhkan adalah tenaga kerja yang jujur, ulet dan tidak gampang menyerah. Tenaga kerja yang bisa direkrut dalam pola kerjasama selama ini adalah dengan menggunakan asumsi ini berdasarkan jumlah franchisee mencapai 20 , kalau dalam satu unit usaha franchise bekerja 2 orang karyawan saja, maka jumlah karyawan yang bisa direkrut mencapai 40 orang.

Jumlah tersebut belum menghitung yang terlibat proses produksi di rumah produksi dan yang bekerja lepas menjadi reseller. Kondisi tersebut sedikit banyak sudah membantu program pemerintah dalam membangun kesempatan kerja terutama untuk pekerja informal.

\section{Pola Packing dan Marketing}

Packing atau pengemasan adalah salah satu strategi perancangan dan pembuatan pembungkus suatu produk. Manfaatnya yaitu dapat sebagai media informasi produk, juga sebagai media penyimpanan dan perlindungan suatu produk agar kualitas produk dapat terjaga dengan baik sekaligus dapat menentukan persepsi konsumen terhadap produk tersebut. Pola pengembangan packing produk cibay bermula hanya menggunakan plastik biasa kemudian seiring perkembangan usaha ini, owner melakukan pengembangan tampilan packing dengan menambahkan opsi kemasan yang terbuat dari kertas karton berlabel cibay. 


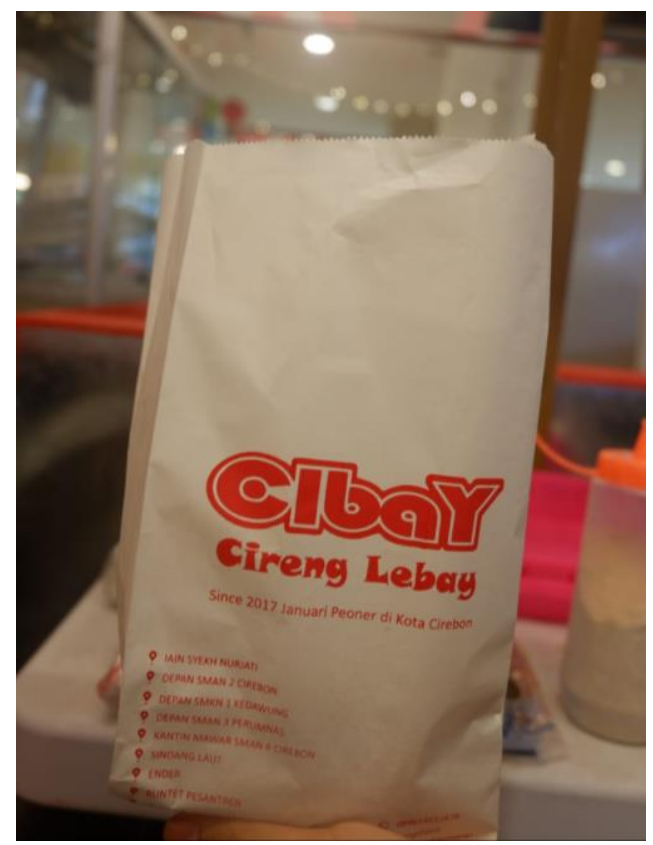

Gambar 5. Packing Untuk Konsumsi langsung

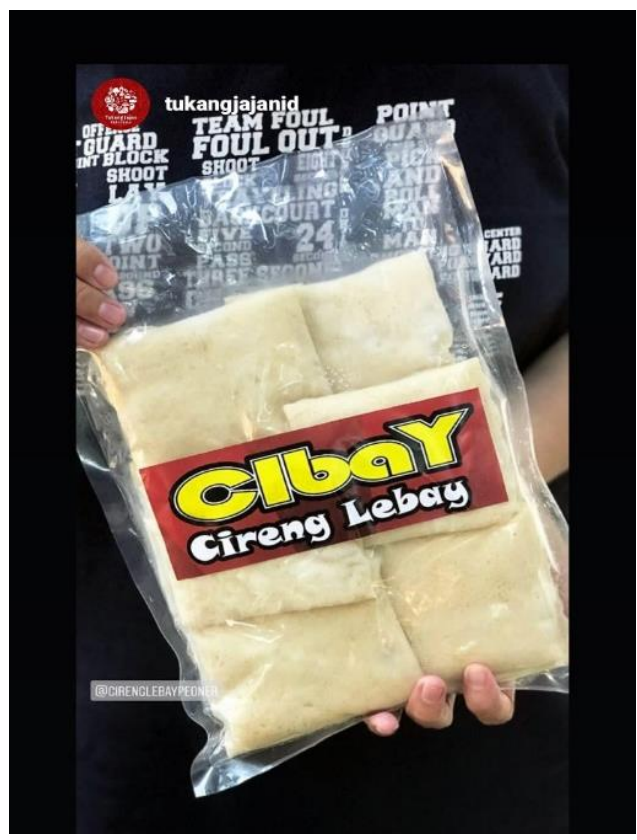

Gambar 6. Packing Untuk Pengiriman luar kota (hasil Inovasi)

Melalui kegiatan pendampingan ini, tim pendamping menyiapkan strategi pengembangan packing produk dengan cara penggunaan vacuum sealer. Vacuum sealer adalah alat yang bekerja secara otomatis untuk menghampakan udara maupun oksigen yang ada didalam kemasan produk. Sehingga volume isi dari produk dapat berkurang dan menghambat pertumbuhan bakteri maupun jamur sekaligus mencegah terjadinya penguapan pada produk cibay. Proses ini dilakukan sebelum proses penyegelan. Vacuum sealer akan sangat membantu untuk mengawetkan produk cibay terutama untuk pengiriman ke luar kota sehingga produk dapat dipastikan tetap higienis, rapi dan tentunya mampu bertahan pada jangka waktu yang panjang.

Marketing adalah serangkaian proses usaha yang dilakukan pelaku usaha dalam memenuhi kebutuhan dan keinginan konsumen. Orientasi kegiatan pemasaran , Pola pemasaran produk yang dijalankan disesuaikan dengan pertimbangan keahlian dan keterampilan yang telah dimiliki pelaku usaha akan menentukan keberhasilan pengembangan pemasaran produk.

Pola pemasaran yang digunakan dalam pengembangan cibay dilakukan melalui dua pola pemasaran yaitu pola marketing tradisional dan pola marketing online. Pola marketing tradisional dikembangkan dengan cara perluasan melalui pelanggan satu ke pelanggan lainya. Adapun pola marketing online yang dilakukan adalah dilakukannya perluasan informasi/ memasang advertensi melalui penggunaan ponsel pintar berupa aplikasi Whastapp, Instagram, serta bergabung dengan 
media promosi secara online seperti group cirebon bribin, kuliner cirebon dan media online lainya untuk meningkatkan efektivitas advertensi dan promosi.

\section{Persepsi Konsumen}

Untuk mendapatkan informasi dan respon mengenai citarasa, harga dan pelayanan tim pendamping mencoba mencari informasi dari konsumen. Konsumen yang kita wawancara merupakan masyarakat yang sudah pernah mengkonsumsi produk pada salah satu atau beberapa outlet cibay. Persepsi konsumen disini bertujuan untuk mengetahui pendapat para konsumen sekaligus sebagai gambaran penilaian kinerja terhadap pola pemberdayaan ekonomi masyarakat melalui pengembangan dan perluasan usaha cibay di kabupaten cirebon dan wilayah sekitarnya.

\section{Citarasa Kelezatan}

Citarasa merupakan salah satu penentu keberhasilan suatu usaha kuliner. Citarasa dapat menggambarkan kinerja usaha kuliner yang dapat menentukan perspektif dan perilaku konsumen terhadap suatu produk. Citarasa yang lezat akan membuat konsumen tertarik dan melakukan pembelian ulang (repeat order) pada produk tersebut. Mayoritas dari konsumen yang berhasil ditemui menyatakan cibay memiliki citarasa yang enak dan lezat dengan keunikan rasanya. Rasanya yang mengandung rempah-rempahan membuat camilan ini memiliki aroma yang unik dan berbeda dengan produk camilan bahkan produk cibay lainnya.

2. Harga

Harga merupakan salah satu strategi pemasaran yang dapat menentukan volume penjualan suatu produk. Harga adalah nilai jual yang telah ditetapkan owner cibay baik kepada reseller maupun pembeli (konsumen). Menurut beberapa konsumen yang dijadikan responden penelitian ini, sebagain besar dari mereka berpendapat bahwa harga yang telah ditetapkan tersebut telah sesuai dengan kualitas (citarasa) produk yang sangat memenuhi harapan konsumen.

\section{Display Makanan}

Display makanan disini dapat berupa bentuk, ukuran, kemasan maupun penataan tempat produk yang ditampilkan kepada konsumen. Display makanan dianggap penting karena dapat menentukan persepsi dan kualitas citra produk pada konsumen sehingga berdampak pada volume penjualan. Terkait dengan hal ini, beberapa diantara mereka mengungkapkan pentingnya peningkatan inovasi dan kualitas pengemasan produk. Hal ini bertujuan agar kualitas produk tetap terjamin dengan baik dan kenyamanan konsumen tetap terjaga. 


\section{Pelayanan}

Pelayanan adalah satu dari beberapa indikator penting penentu kualitas suatu produk. Pelayanan dapat menunjukkan besarnya tingkat kepekaan dan perhatian pelayan dalam melayani konsumen. Pelayann disini berupa keramahan dan kesopanan pelayan, dapat pula berupa kecepatan penyajian produk yang dilakukan pelayan. Berdasarkan pengumpulan informasi pada konsumen cibay, ditemukan bukti bahwa pelayanan yang diberikan kepada konsumen cibay sebagian besar menilai baik. Hal ini berarti pelayanan yang diberikan kepada konsumen telah memenuhi harapan dan keinginan serta kepuasan pelayanan terhadap para konsumen cibay.

\section{KESIMPULAN DAN SARAN}

Kunci dari keberhasilan usaha makanan olahan adalah citasara, harga dan kepercayaan orang untuk membelinya kembali (repeat oder). Untuk mewujudkan itu perlu juga mulai ditingkatkan kualitas produksinya dengan mulai menginisiasi pengurusan kepemilikan PIRT, bahkan mulai memikirkan juga mengurus sertifikat halal. Karena hal tersebut bisa menjadi pendukung image dan meningkatkan kepercayaan konsumen dan masyarakat terhadap produk cibay.

\section{UCAPAN TERIMAKASIH}

Ucapan terimakasih disampaikan kepa Ibu Nisa Anastasia selaku owner usaha cibay yang sudah banyak memberikan informasi dan meberikan ruang kepada tim pengabdian untuk sama-sama belajar, segenap mitra usaha franchise dan reseller cibay, para konsumen setia cibay.

\section{DAFTAR PUSTAKA}

Alma, B. (2013). Kewirausahaan. Bandung: Alfabeta.

Hasanah, N. (2019). Analisis Mekanisme Dropshipper dan Reseller di Toko Online S3 Komputer Surabaya. UIN Sunan Ampel Surabaya. https://doi.org/10.4324/9781315853178

Indrawan, R., \& Yaniawati, P. (2017). Metodologi Penelitian; Kuantitatif, Kualitatif, dan Campuran (untuk Manajemen, Pembangunan dan Pendidikan). Bandung: Refika Aditama.

Karamoy, A. (2011). Waralaba-Jalur Bebas Hambatan Menjadi Pengusaha Sukses. Gramedia Pustaka Utama. 
Nurdiyanto, H., \& Meilia, H. (2016). Sistem Pendukung Keputusan Penentuan Prioritas Pengembangan Industri Kecil Dan Menengah Di Lampung Tengah Menggunakan Analitical Hierarchy Process (Ahp). Semnasteknomedia, 4(1), 37-42. Retrieved from https://ojs.amikom.ac.id/index.php/semnasteknomedia/article/view/1163

Putra, A. H. (2016). Peran UMKM dalam Pembangunan dan Kesejahteraan Masyarakat Kabupaten Blora. Jurnal Analisa Sosiologi, 5(2), 40-52.

Rachmadi, bambang N. (2007). Franchising; Membedah Tawaran Franchise Lokal di Indonesia. Jakarta: Gramedia Pustaka Utama.

Rifa'i, B. (2013). Efektivitas Pemberdayaan Usaha Mikro Kecil dan Menengah (UMKM) Krupuk Ikan dalam Program Pengembangan Labsite Pemberdayaan Masyarakat Desa Kedung Rejo Kecamatan Jabon Kabupaten Sidoarjo. Jurnal Kebijakan Dan Manajemen Publik, 1(1), 130136.

Santosa, S. H., Prihatini, D., Purwanto, A., Jumiati, A., \& Susilo, D. (2016). Pengembangan pola kemitraan dalam rangka pengentasan kemiskinan di jawa timur. In Dinamika Global: Rebranding Keunggulan Kompetitif Berbasis Kearifan Lokal (pp. 601-611). Jember: Universitas Jember.

Tampubolon, J., Ginting Sugihen, B., Samet, M., Susanto, D., \& Sumardjo. (2006). Pemberdayaan Masyarakat Melalui Pendekatan Kelompok (Kasus Pemberdayaan Masyarakat Miskin melalui Pendekatan Kelompok Usaha Bersama (KUBE)). Jurnal Penyuluhan, 2(2), 10-22.

Theresia, A., Andini, K. S., Nugraha, P. G. ., \& Mardikanto, T. (2014). Pembangunan Berbasis Masyarakat. Bandung: Alfabeta.

Tim Penelitian dan Pengembangan Perkreditan dan UMKM. (2009). Pola Pembiayaan Usaha Kecil Usaha Franchiese. Jakarta: Bank Indonesia. 